\title{
ESTIMATION OF AQUIFER PARAMETERS IN ERHO, NIGERIA USING THE COOPER-JACOB EVALUATION METHOD
}

\author{
Ochuko Anomohanran and Ruth E. Iserhien-Emekeme
}

Physics Department, Faculty of Science, Delta State University, Abraka, Nigeria

Received 2014-08-21; Revised 2014-10-01; Accepted 2014-10-01

\begin{abstract}
The aim of this study was to determine the aquifer parameters in Erho, Nigeria. This was carried out by drilling three test wells and three observation wells in the study location. Water was pumped from the test wells at a constant rate while the drawdown in the observation wells was determined as a function of time. The data obtained were subjected to graphical and analytical evaluation using the Cooper-Jacob method. The result revealed that the mean values of the transmissivity, storage coefficient and specific capacity of the aquifer layer are $6.15 \times 10^{-2} \mathrm{~m}^{2} / \mathrm{min}, 9.3 \times 10^{-4}$ and $0.33 \mathrm{~m}^{2} / \mathrm{min}$ respectively. Analysis of the results indicated that the aquifer will be very productive and able to supply sufficient quantity of water for the people. The result also revealed that the aquifer is confined and therefore dependable to provide good quality water for the people living in the area.
\end{abstract}

Keywords: Groundwater, Aquifer Parameters, Pumping Test, Transmissivity, Storage Coefficient, Specific Capacity

\section{INTRODUCTION}

Groundwater is described as that water which is obtained from the unconsolidated soil or rock formations (Anomohanran, 2013a). Formations, which are capable of providing water in large quantities, are known as aquifers (Oseji et al., 2005). When an aquifer is located below a low permeability layer, the water in the aquifer is said to be confined. The pumping of water from an aquifer through a well over a long period of time, results in the drop of the water level in that aquifer. This drop in water level causes the water around the well to flow toward the well. Researchers and groundwater providers have employed different geophysical procedures in determining the flow properties of groundwater aquifer. These procedures include electrical resistivity techniques, geophysical well logging and pumping test.

The electrical resistivity technique has been used by quite a number of researchers, some of whom are (Akaolisa, 2006; Oseji et al., 2005; Khalil and Monteria,
2009; Yang and Lee, 2002; Onu, 2003; Nejad, 2009; Majumdar and Das, 2011), to determine either the hydraulic conductivity, transmissivity or the specific yield of the groundwater aquifer. The simple reason for adopting this method is because the cost is effectively low and the field operation is relatively simple when compared to other techniques (Anomohanran, 2014a).

Okiongbo and Akpofure (2012), stated that the use of pumping test and well logging in evaluating aquifer parameters requires a number of equipment to carry them out. This is the reason why these processes are comparatively more expensive when compared with the electrical resistivity method. Some researchers who have used the pumping test and logging methods to evaluate aquifer parameters include (Anomohanran, 2013b; 2014b; Gogoi, 2013; Halford et al., 2006; Rajasekhar et al., 2014; Straface et al., 2007; Tizro et al., 2014).

Aquifer parameters which can be derived from pumping test include the transmissivity, storage Corresponding Author: Ochuko Anomohanran, Physics Department, Faculty of Science, Delta State University, Abraka, Nigeria 
coefficient, hydraulic conductivity, specific yield and specific capacity of the well. The transmissivity of an aquifer is explained as the rate at which water flows through the aquifer under a unit width and a unit hydraulic gradient. It is obtained by multiplying the aquifer's hydraulic conductivity by the aquifer thickness. The higher the value of the transmissivity, the more productive the aquifer and the smaller the value of the drawdown from the well. The hydraulic conductivity of an aquifer is described as the pace at which the water flows in the aquifer. It is measured in metre cube per day (Anomohanran, 2014b).

The productivity of an aquifer can be expressed in terms of its storage coefficient. The storage coefficient is explained as the amount of water an aquifer takes into storage or discharges from storage per unit surface area of the aquifer per unit change in the component of head normal to that surface (Todd, 2004). The storage coefficient for a confined aquifer falls within the range of 0.00005 and 0.005 while the storage coefficient of an unconfined aquifer ranges between 0.02 and 0.3. The storage coefficient of a semi confined aquifer is between the range of 0.005 and 0.02 (Fetter, 2007).

The specific capacity of a drilled well is the rate at which water is pumped out of the well divided by the fall in water level. It is a very valuable number that can be used to determine the pumping rate or the maximum yield for a well. The specific capacity that is obtained immediately after a well is drilled is the highest value that can ever be obtained from such a well. This value is therefore the touchstone for comparing, monitoring or evaluating well performance (Johnson, 2005; Khalil et al., 2011). The specific capacity is a measure of the productivity of a well and it is a fact that the larger the specific capacity, the better the well (Todd, 2004).

The amount of water available in a well can be as important as the quality of the water (DES, 2010). This is why every driller or well owner is concerned about the quantity of water the well is capable of producing and how reliable the production will be with respect to time. This is the reason why so much efforts have been made to offer solutions to the global water crises (Utom et al., 2012).

The aim of this survey is therefore to determine the aquifer characteristics of the study area. This will be carried out through the evaluation of the storage coefficient, transmissivity and specific capacity of the aquifer. The outcome of this survey will act as an authentic tool for carrying out maintenance or performance evaluation of wells in the area.

\section{THEORY}

When an aquifer is pumped at a constant rate, the influence of the discharge according to Todd (2004) extends outward with time. The rate of diminution of the water level when multiplied by the specific coefficient gives the discharge. The rate is known to decrease as the effect of pumping increases in the surrounding region. The applicable differential equation that explains this phenomenon is presented by Todd (2004) as:

$$
\frac{\delta^{2} h}{\delta d^{2}}+\frac{1}{d} \frac{\delta h}{\delta d}=\frac{S}{T} \frac{\delta h}{\delta t}
$$

where, $\mathrm{T}$ is transmissivity, $\mathrm{S}$ is storage coefficient, $\mathrm{h}$ is the head, $d$ is the distance from the pumped well and $t$ is the time of pumping. According to Todd (2004), Theis developed a solution to Equation 1 based on the similarity between groundwater flow and heat conduction. By assuming that the well can be replaced by a sink of constant strength and the conditions that $\mathrm{h}=\mathrm{h}_{\mathrm{o}}$ for $\mathrm{t}=0$ and $\mathrm{h} \rightarrow \mathrm{h}_{\mathrm{o}}$ as $\mathrm{d} \rightarrow \infty$ for $t \geq 0$, Theis obtain a solution for Equation 1 as:

$l=\frac{Q}{4 \pi T} \int_{u}^{\infty} \frac{e^{-u}}{u} d u$

where, $l$ is the drawdown, $\mathrm{Q}$ is the constant well discharge and $\mathrm{u}$ is given as:

$u=\frac{d^{2} S}{4 T t}$

The drawdown $(l)$ is the difference between the depth of the water before the well was pumped and the depth of the water at a given time after pumping had commenced (Fetter, 2007).

Expanding Equation 2 as a convergent series gives the Equation as express by Theis to be (Fetter, 2007):

$l=\frac{Q}{4 \pi T}\left[-0.5772-\operatorname{In} u+u-\frac{u^{2}}{2 \bullet 2 !}+\frac{u^{3}}{3 \bullet 3 !}+\ldots\right]$

Theis thus simplified Equation 3 and 4 to give Equation 5 and 6:

$\frac{d^{2}}{t}=\left(\frac{4 T}{S}\right) u$

And: 
$l=\left(\frac{Q}{4 \pi T}\right) W(u)$

where, $\mathrm{W}(\mathrm{u})$ is called the well function.

The values of the drawdown $(l)$ were plotted against the values of $\mathrm{d}^{2} / \mathrm{t}$ on a logarithmic graph sheet. A standard type curve of $\mathrm{W}(\mathrm{u})$ versus $\mathrm{u}$ is also plotted using the same scale as that of drawdown against $\mathrm{d}^{2} / \mathrm{t}$. The observed drawdown-time graph is then superimposed on the type curve. Keeping the coordinate axis of the two curves parallel and adjusting the graphs until a position is found whereby most of the plotted points of the observed data fall on a segment of the type curve. The coordinates of this matched position are determined. This thus gives the values of $\mathrm{W}(\mathrm{u}), \mathrm{u}, \mathrm{S}$ and $\mathrm{d}^{2} / \mathrm{t}$ from which $\mathrm{S}$ and $\mathrm{T}$ are determined.

Cooper and Jacob thus considered Equation 4 and observed that if the distance between the pumped well and the observation well ' $\mathrm{d}$ ' is small while the time $\mathrm{t}$ is large, u will eventually become small (Fetter, 2007). Hence, Equation 4 becomes very small after the first two terms. According to Todd (2004), the Theis Equation was re-defined by Cooper and Jacob as:

$l=\frac{Q}{4 \pi T}\left[-0.5772-\operatorname{In} \frac{d^{2} S}{4 T t}\right]$

Converting Equation 7 to decimal logarithms gives:

$l=\frac{2.30 Q}{4 \pi T} \log _{10} \frac{2.25 T t}{d^{2} S}$

In order to resolve the problem of superposing the two curves and finding the value of the various parameters, Cooper and Jacob extended the work of Theis analytically to obtain equations which solves the problem of curve matching. The graph of the drawdown against the logarithm of time will yield a straight line which can be extended to give $\mathrm{t}=\mathrm{t}_{\mathrm{o}}$ as $\mathrm{h}-\mathrm{h}_{\mathrm{o}}=0$. Applying these conditions to Equation 8 gives Equation 9:

$$
\frac{2.30 Q}{4 \pi T} \log _{10} \frac{2.25 T t}{d^{2} S}=0
$$

And Equation 9 can thus be written as:

$$
\frac{2.25 T t_{o}}{d^{2} S}=1
$$

Hence, the storage coefficient is obtained as Equation 11:
$S=\frac{2.25 T t_{o}}{d^{2}}$

Considering that $\mathrm{t} / \mathrm{t}_{\mathrm{o}}=10$, then the $\log _{10} \mathrm{t} / \mathrm{t}_{\mathrm{o}}=1$. If $l$ is the drawdown and $\Delta l$ the drawdown per log circle of time, the transmissivity is expressed by Equation 12 as:

$T=\frac{2.30 Q}{4 \pi \Delta l}$

\section{MATERIALS AND METHODS}

\subsection{Location and Geology of the Area}

This study was carried out in Erho, located in Delta State, Nigeria and situated within longitude $6.07^{\circ}$ and $6.09^{\circ} \mathrm{E}$ and latitude $5.74^{\circ}$ and $5.78^{\circ} \mathrm{N}$ (Fig. 1). The topography is relatively flat. The region is characterised by two climatic seasons, namely the raining season and the dry season. The raining season extends from April to October while the dry season runs from November to March. The primary origin of groundwater recharge is believed to be the rainfall which is in abundance in the area (Okiongbo and Akpofure, 2012). The survey location falls within the coastal sedimentary basin of Nigeria which has been the scene of three depositional sequences. The first sequence is associated with the marine incursion which commenced from the middle Cretaceous and ended in Santonian time in what is called the mild folding stage. The second sequence started in the late Cretaceous and ended in Paleocene period. This period gave rise to what is called the growth of a proto niger delta. The third depositional sequence began from Eocene to Recent. This sequence is identified to be a furtherance of the growth of the main niger delta (Short and Stauble, 1967). Three lithologic structures which are associated with the survey area are the Benin, Agbada and Akata Formations. The Benin Formation consists of approximately ninety percent sand and is about $2000 \mathrm{~m}$ thick. This Formation has yielded a good number of prolific boreholes in the area. The Agbada Formation consists of fifty percent sand and fifty percent shale while the Akata Formation consists mainly of shale bed believed to be the source rock for hydrocarbon.

\subsection{Field Technique}

Two boreholes each situated twenty metres apart were drilled in three different locations in the study area to determine the aquifer parameters. One of the boreholes was designated test well while the other well was referred to as observation well. 
A submersible pumping machine of $0.75 \mathrm{~kW}$ capacity was installed in the test well and a $1.8 \mathrm{~kW}$ generator was used to power the pump. The well was pumped at a constant rate of $0.08 \mathrm{~m}^{3} / \mathrm{min}$. At some interval of time, the depth of the water level in the observation well was measured. This process was carried out in all three locations and the drawdown was determined. The drawdown is obtained by subtracting the water level at a given time from the water level before pumping commenced.

The difference in the elevation of the water level before and after pumping was plotted against time of pumping on a semi-logarithmic graph sheet for the different locations. The graphs were used to determine the drawdown per log cycle of time $(\Delta \mathrm{L})$ and the time intercept $\left(\mathrm{t}_{\mathrm{o}}\right)$. These two values were then substituted into the Cooper-Jacob equations to evaluate the storage coefficient, transmissivity and specific capacity of the aquifer.

\section{RESULTS}

The plot of the water level in the observation well versus the time since pumping commenced in the test well is presented as Fig. 2a, while the plot of the drawdown versus the time of pumping is presented as Fig. 2b. A graph sheet which has the $\mathrm{x}$-axis designed in logarithm scale and the $y$-axis in arithmetic scale was used to plot the graph of drawdown against the time of pumping for the three locations and the result presented as shown in Fig. 3. Figure 3 was used to calculate the physical parameters such as drawdown per $\log$ cycle of time $(\Delta \mathrm{l})$ and $\mathrm{t}_{\mathrm{o}}$. These parameters were then substituted into the Cooper-Jacob equations to compute the aquifer storage coefficient, transmissivity and specific capacity.

Well 1: The aquifer parameters for well 1 are obtained by substituting the values of the various parameters shown in Fig. 3a into Equation 12 to give the transmissivity of well I as:

$$
T_{1}=\frac{2,30 \times 0,08}{4 \pi \times 0: 23}=0.064 \mathrm{~m}^{2} / \mathrm{min}
$$

The storage coefficient for well 1 was obtained using Equation 11 as:

$$
S_{1}=\frac{2.25 \times 0.064 \times 3}{20^{2}}=0.0011
$$

The specific capacity of well 1 is obtained by dividing the discharge by the drawdown per log cycle of time as:

$$
s_{y}=\frac{Q}{\Delta l}=\frac{0.00}{0.22}=0.35 \mathrm{~m}^{2} / \mathrm{min}
$$

Well 2: The aquifer parameters for well 2 are obtained by substituting the values of the various parameters shown in Fig. 3b into Equation 10. This gives:

$$
T_{2}=\frac{30 \times 000}{4 \pi \times 0: 2 s}=0.059 \mathrm{~m}^{2} / \mathrm{min}
$$

The storage coefficient for well 2 was obtained using Equation 9 as:

$$
S_{2}=\frac{2.25 \times 0.059 \times 3}{20^{2}}=0.0010
$$

The specific capacity of well 2 is obtained as:

$$
s_{y}=\frac{Q}{\Delta I}=\frac{0.08}{0.23}=0.33 \mathrm{~m}^{2} / \mathrm{min}
$$

Well 3: The aquifer parameters for well 3 are obtained by substituting the values of the various parameters shown in Fig. 3c into Equation 10 as:

$$
T_{2}=\frac{230 \times 008}{4 \pi \times 0.24}=0.061 \mathrm{~m}^{2} / \mathrm{min}
$$

The storage coefficient for well 3 was obtained using Equation 9 as:

$$
S_{3}=\frac{2.25 \times 0.061 \times 2}{20^{2}}=0.0007
$$

The specific capacity of well 3 is obtained as:

$$
s_{y}=\frac{Q}{M !}=\frac{0.08}{0: 2}=0.32 \mathrm{~m}^{2} / \mathrm{min}
$$

The results obtained for the various parameters are presented as shown in Table 1. This table contains the result of the aquifer transmissivity, storage coefficient and specific capacity of the three observation wells. 
Ochuko Anomohanran and Ruth E. Iserhien-Emekeme / American Journal of Environmental Sciences 10 (5): 500-508, 2014

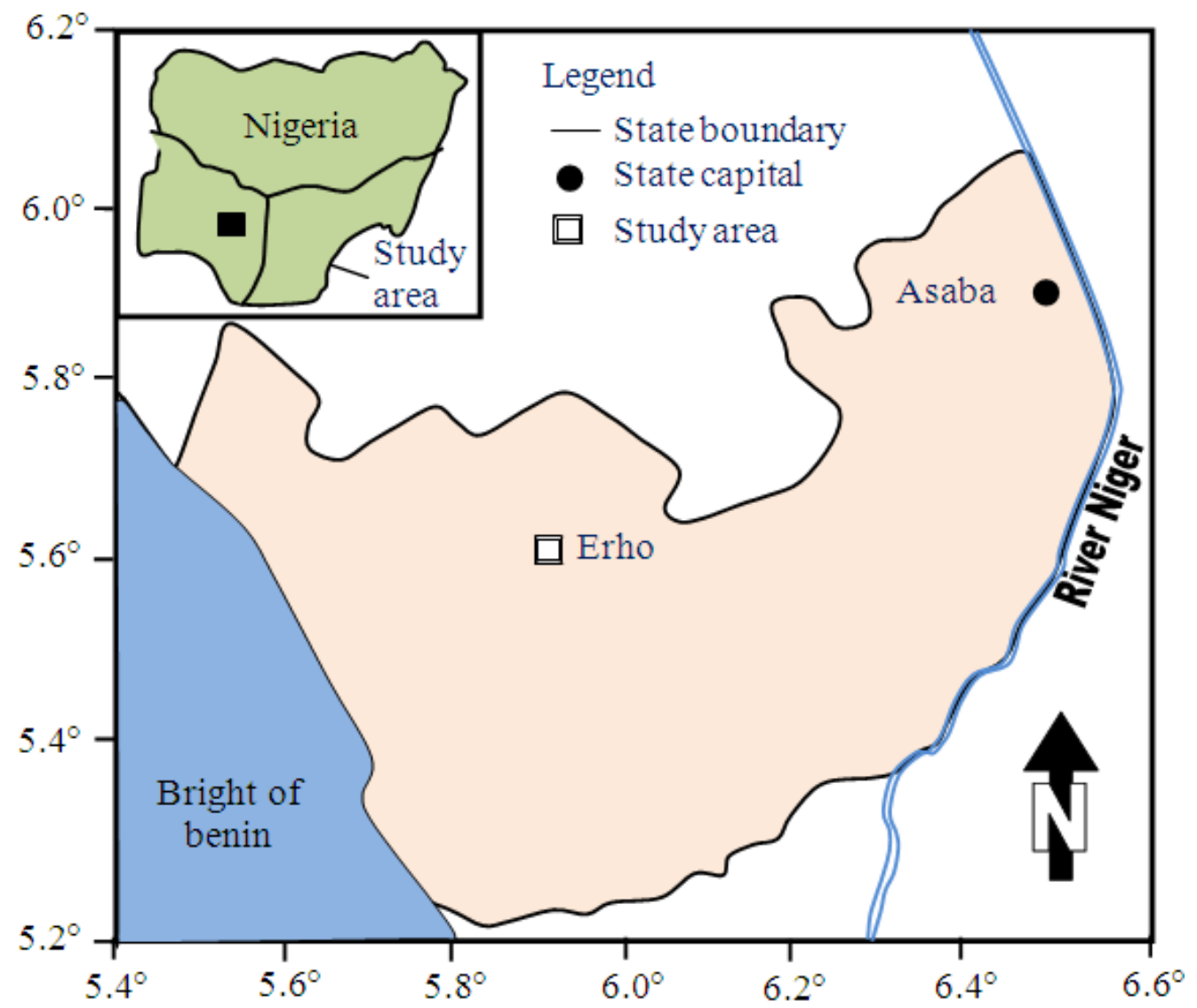

Fig. 1. Map of Delta State showing the study area

"Well $1 \quad \square$ Well $2 \quad$ well 3

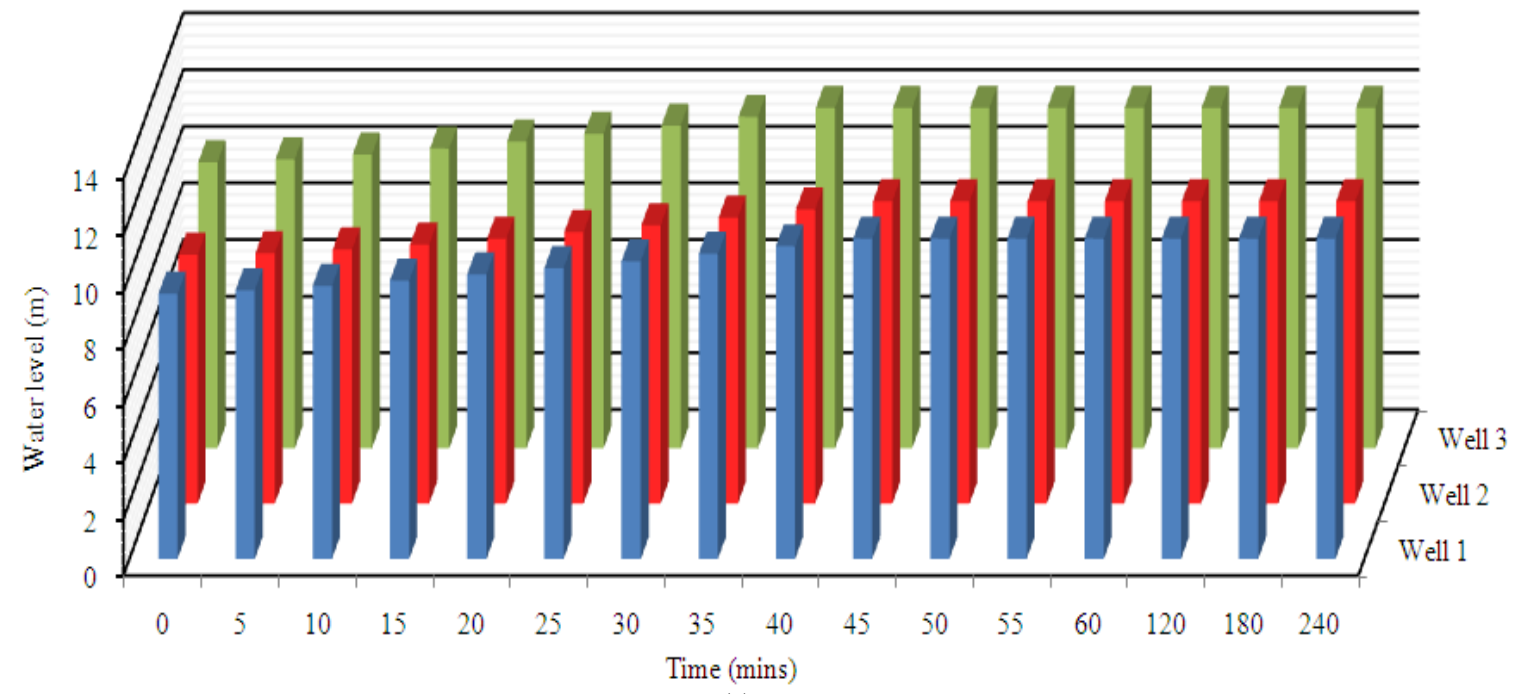

(a) 
Ochuko Anomohanran and Ruth E. Iserhien-Emekeme / American Journal of Environmental Sciences 10 (5): 500-508, 2014

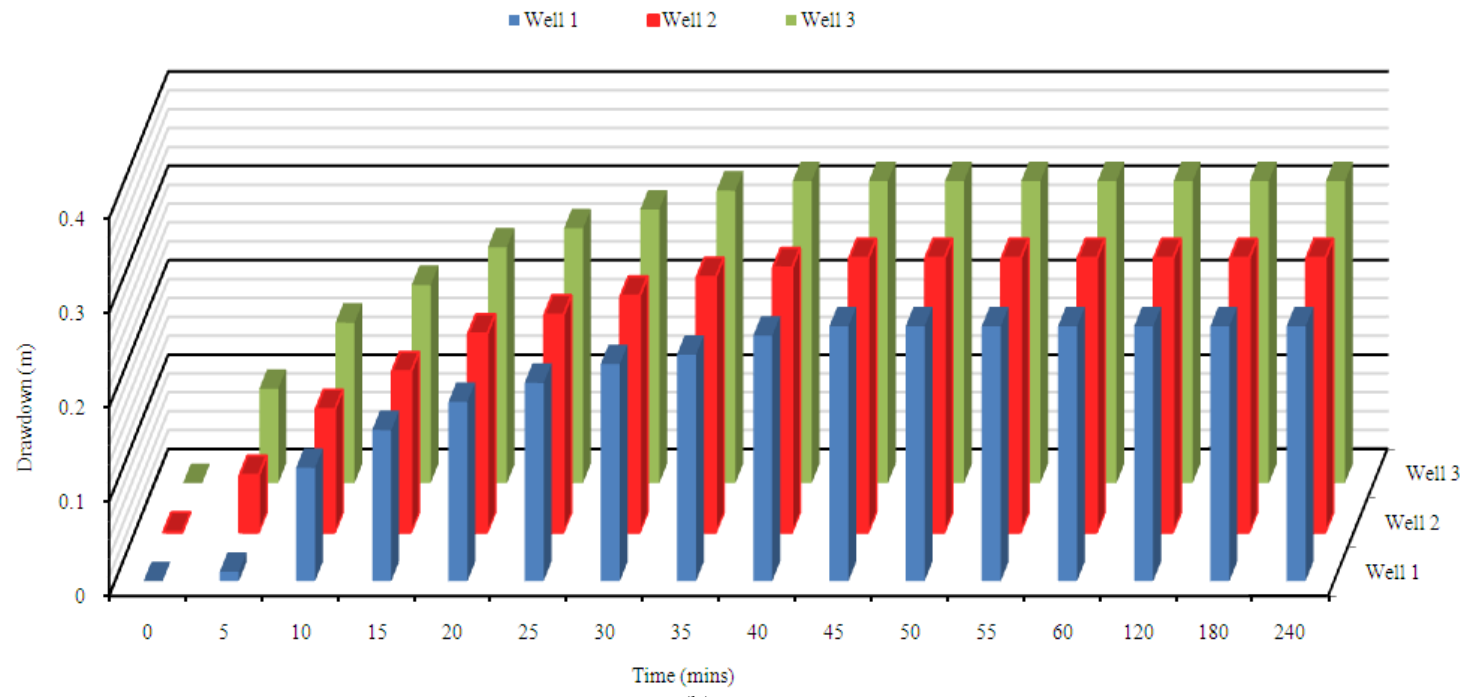

(b)

Fig. 2. (a) Plot of water level versus time of pumping. (b) Plot of drawdown versus time of pumping

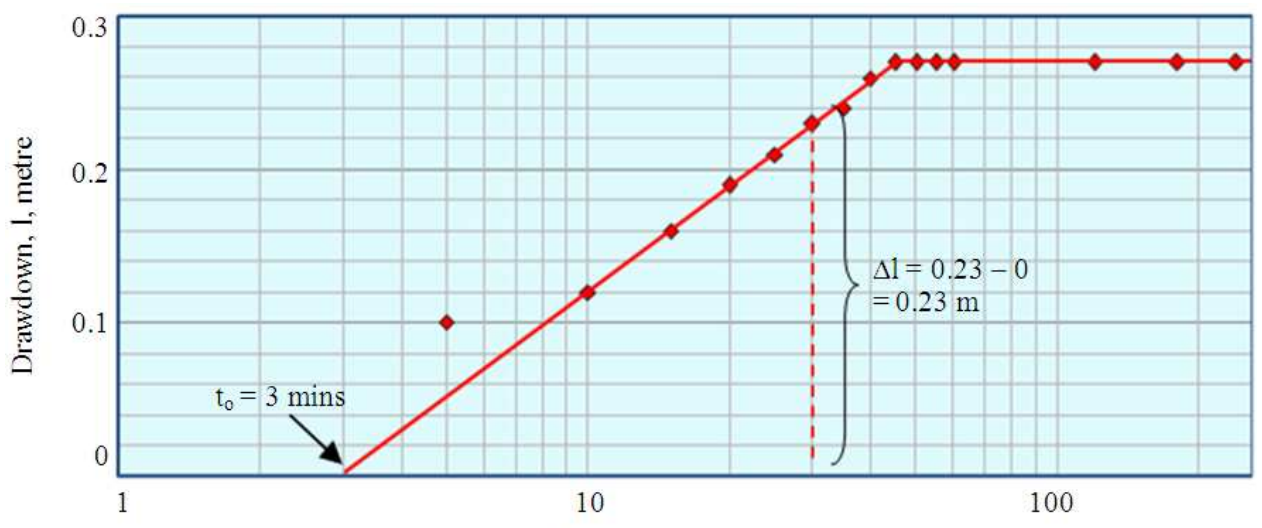

Time of pumping, $\mathrm{t}$, minutes

(a)

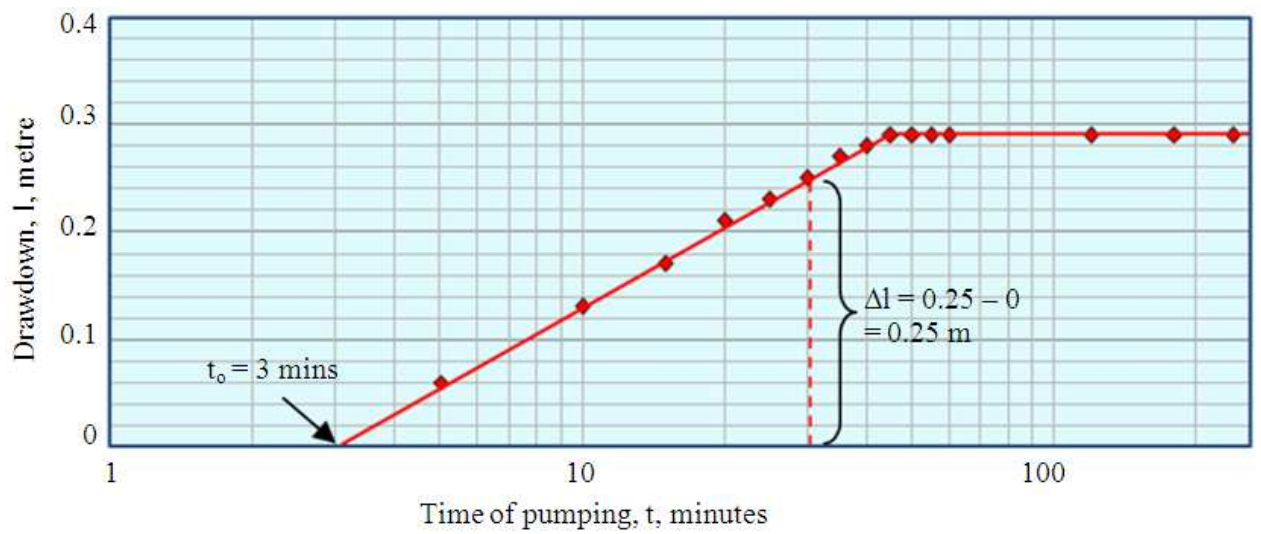

(b) 


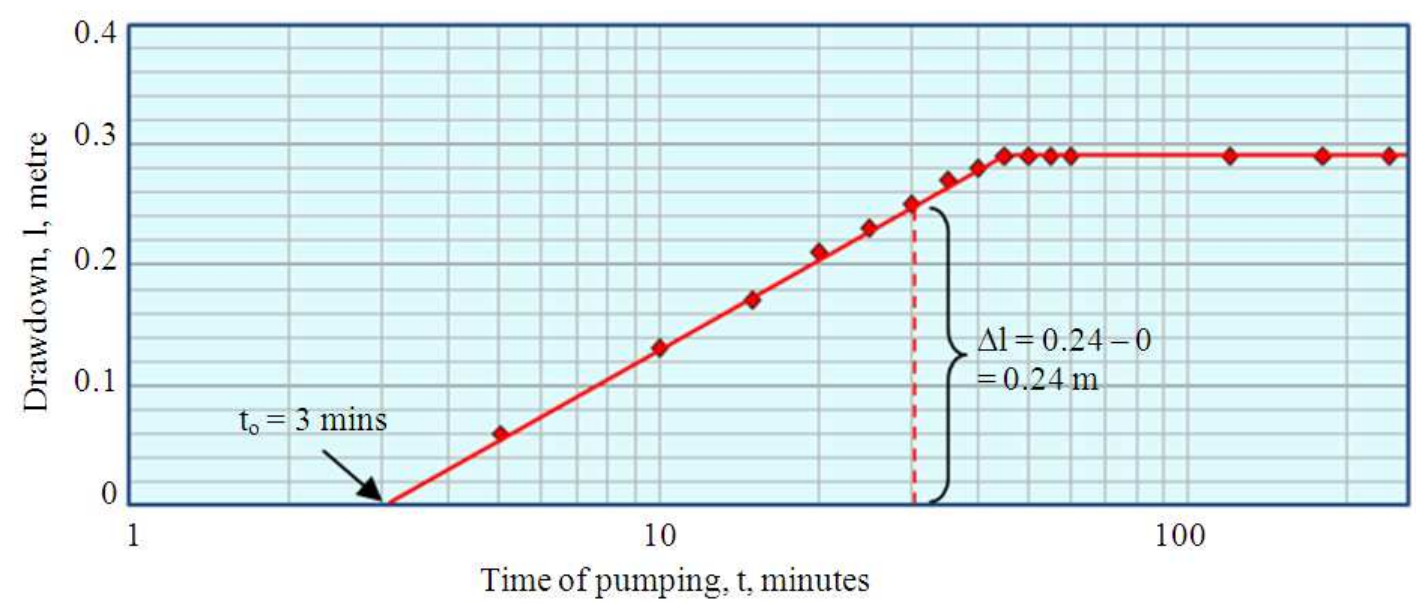

(c)

Fig. 3. Plot of Drawdown as a function of time of pumping (a) Well 1; (b) Well 2; (c) Well 3

Table 1. Results of the various aquifer parameters obtained from the drilled wells

\begin{tabular}{llll}
\hline Wells & Transmissivity $\left(\mathrm{m}^{2} / \mathrm{min}\right)$ & Storativity & Specific Capacity $\left(\mathrm{m}^{2} / \mathrm{min}\right)$ \\
\hline Well 1 & 0.064 & 0.0011 & 0.35 \\
Well 2 & 0.059 & 0.0010 & 0.33 \\
Well 3 & 0.061 & 0.0007 & 0.32 \\
\hline
\end{tabular}

\section{DISCUSSION}

The amount of water that can be transmitted horizontally by the aquifer in this study was estimated by a measure of the transmissivity which was obtained as $0.064,0.059$ and $0.061 \mathrm{~m}^{2} / \mathrm{min}$ for wells 1,2 and 3 respectively (Table 1). The mean value of the aquifer transmissivity was also obtained as $0.0615 \mathrm{~m}^{2} / \mathrm{min}$ for the area. This value suggests that the transmission rate of the groundwater in the aquifer is high and that the aquifer is prolific and is thus capable of supplying adequate quantity of water for the people. The values also agreed with the result of a similar survey carried out in Igun, Eku and Oria to evaluate their aquifer characteristics. The researcher was able to show that the transmissivity of the area range between 0.068 and $0.070 \mathrm{~m}^{2} / \mathrm{min}$ (Anomohanran, 2014a). The result is also in agreement with another study carried out in some locations in Delta Central District of Nigeria. The result showed that the rate at which the groundwater is transmitted through the aquifer in this district was obtained as $0.022 \mathrm{~m}^{2} / \mathrm{min}$ (Anomohanran, $2014 b)$. This claim is also in agreement with the work of Rajasekhar et al. (2014) who used the pumping test method to derive the transmissivity of confined aquifer and obtained it as $0.065 \mathrm{~m}^{2} / \mathrm{min}$.
The water bearing ability of the aquifer from the three locations under study were determined through the evaluation of the storage coefficient. The computed values revealed that the storage coefficients of the aquifer are $0.0011,0.0010,0.0007$ for wells 1,2 and 3 respectively. The mean value of the storage coefficient was computed as 0.00093 . These values correspond to the storage coefficient of a confined aquifer (Todd, 2004; Anomohanran, 2014b). This finding is an indication that enough pressure exists within the aquifer to produce substantial quantity of water for the people. This claim is also in agreement with the work of Rajasekhar et al. (2014) who used the pumping test method to derive the transmissivity of confined aquifer and obtained it as $0.065 \mathrm{~m}^{2} / \mathrm{min}$. The significance of this is that the aquifer is secured and is not vulnerable to pollution infiltrating from the surface layer. It is therefore dependable as a source of domestic water supply.

A measure of the productivity of the wells was also determined in this study and the findings indicate that the specific capacity of wells 1,2 and 3 are $0.35,0.33$ and $0.32 \mathrm{~m}^{2} / \mathrm{min}$ respectively. The mean specific capacity for the area was obtained as $0.33 \mathrm{~m}^{2} / \mathrm{min}$. The values obtained for the specific capacity indicate that the well is capable of providing sufficient amount 
of water for the people in the area. The value of the specific capacity will be very useful in comparing the efficiency of the well over time and also for the maintenance of other wells in the area.

Even though the result indicates that the aquifer in the study area is significantly protected by an aquitard, it is not a proof that the water quality is one hundred percent guaranteed. This fact notwithstanding, this study was unable to determine the chemical properties of the groundwater to give certainty to the groundwater quality.

\section{CONCLUSION}

In this stduy, the principle of pumping test involving the use of Cooper-Jacob evaluation procedure has been used to determine the properties of the aquifer in Erho, Nigeria. The outcome of the survey has revealed that the aquifer can effectively produce enough quantity of water for the generality of people in the area. The result of this survey has also identified the aquifer as confined and therefore dependable to provide good quality water for the people in the area. The findings of this survey will act as a reference point for carrying out the monitoring and performance evaluation for other wells in the survey area.

\section{REFERENCES}

Akaolisa, C., 2006. Aquifer transmissivity and basement structure determination using resistivity sounding at Jos plateau state Nigeria. Environ. Monitor. Assessment, 114: 27-34. DOI: $10.1007 / \mathrm{s} 10661-006-1075-8$

Anomohanran, O., 2013a. Geophysical investigation of groundwater potential in Ukelegbe, Nigeria. J. Applied Sci., 13: 119-125. DOI: 10.3923/jas.2013

Anomohanran, O., 2013b. Evaluation of aquifer characteristics in echi, delta state, Nigeria using well logging and pumping test method. Am. J. Applied Sci., 10: 1263-1269. DOI: 10.3844/ajassp.2013.1263.1269

Anomohanran, O., 2014a. Assessment of groundwater potential and aquifer characteristics in the vicinity of Igun, Eku and Oria in delta state, Nigeria. J. Water Resource Protect., 6: 731-803. DOI: 10.4236/jwarp.2014.68070

Anomohanran, O., 2014b. Hydrogeophysical and hydrogeological investigations of groundwater resources in delta central, Nigeria. J. Taibah Uni. Sci., DOI: 10.1016/j.jtusci.2014.06.003
DES, 2010. Recommended minimum water supply capacity for private wells. DES Environmental Fact Sheet, WD-DWGB-1-8.

Fetter, C.W., 2007. Applied Hydrogeology. 4th Edn., Prentice Hall, Upper Saddle River, ISBN-10: 0130882399, pp: 598.

Gogoi, U., 2013. Determination of aquifer parameters of the shallow aquifers of Barak valley, Assam, India. Int. Bulletin Water Resources Dev., 1: 1-13.

Halford, K.J., W.D. Wright and R.P. Schreiber, 2006. Interpretation of Transmissivity estimates from singlewell pumping aquifer tests. Ground Water, 44: 467471. DOI: $10.1111 / \mathrm{j} .1745-6584.2005 .00151 . \mathrm{x}$

Johnson, T., 2005. A measure of well performance, well problems and aquifer Transmissivity. WRD Technical Bulletin, 2: 1-2.

Khalil, M.A. and F.A.S. Monterio, 2009. Influence of degree of saturation in the electric resistivityhydraulic conductivity relationship. Surv. Geophys., 30: 601-615. DOI: 10.1007/s10712-009-9072-4

Khalil, M.A., E.C. Ramalho and F.A.M. Santos, 2011. Using resistivity $\operatorname{logs}$ to estimate hydraulic conductivity of a Nubian sandstone aquifer in Southern Egypt. Near Surface Geophys., 9: 349-355. DOI: $10.3997 / 1873-0604.2011009$

Majumdar, R.K. and D. Das, 2011. Hydrological characterization and estimation of aquifer properties from electrical sounding data in Sagar Island region, South 24 parganas, West Bengal, India. Asian J. Earth Sci., 4: 60-74. DOI: 10.3923/ajes.2011.60.74

Nejad, H.T., 2009. Geoelectric investigation of the aquifer characteristics and groundwater potential in behbahan azad university farm, Khuzestan Province, Iran. J. Applied Sci., 9: 3691-3698. DOI: 10.3923/jas.2009.3691.3698

Okiongbo, K. S. and E. Akpofure, 2012. Determination of aquifer properties and groundwater vulnerability mapping using geoelectric method in Yenagoa city and its environs in bayelsa state, South Nigeria. J. Water Resource Protect., 4: 354-362. DOI: 10.4236/jwarp.2012.46039

Onu, N.N., 2003. Estimates of the relative specific yield of aquifers from geo-electrical sounding data of the coastal plains of southeastern Nigeria. J. Technol. Educ. Nigeria, 8: 69-83. DOI: 10.4314/joten.v8i1.35641

Oseji, J.O., E.A. Atakpo and E.C. Okolie, 2005. Geoelectric investigation of the aquifer characteristics and groundwater potential in Kwale, Delta State, Nigeria. J. Applied Sci. Environ. Manage., 9: 157-160. 
Rajasekhar, P., K.P. Vimal and M. Mansoor, 2014. Determination of confined aquifer parameters by Sushil K. Singh method. Am. Int. J. Res. Sci. Technol. Eng. Math., 5: 158-163.

Short, K.C. and A.J. Staeuble, 1967. Outline of geology of Niger delta. AAPG Bulletin, 51: 761-779.

Straface, S., C. Fallico, S. Troisi, E. Rizzo and A. Revil, 2007. An Inverse procedure to estimate transmissivity from heads and sp signals. Ground Water, 45: 420-428. DOI: 10.1111/j.1745-6584.2007.00310x

Tizro, T.A., K.S. Voudouris and M. Kamali, 2014. Comparative study of step drawdown and constant discharge tests to determine the aquifer Transmissivity: The Kangavar aquifer case study, Iran. J. Water Resource Hydraulic Eng., 3: 12-21.
Todd, D.K., 2004. Groundwater Hydrology. 2nd Edn., John Wiley, New York.

Utom, A.U., B.I. Odoh and A.U. Okoro, 2012. Estimation of aquifer Transmissivity using Dar Zarrouk parameters derived from surface resistivity measurements: A case history from parts of Enugu town (Nigeria). J. Water Resource Protect., 4: 9931000. DOI: 10.4236/jwarp.2012.412115

Yang, C. and V. Lee, 2002. Using direct current resistivity sounding and geostatistics to aid in hydrogeological studies in the choshuichi alluvial fan. Taiwan Ground Water, 40: 165-173. 